\title{
Assessment of polycyclic aromatic hydrocarbon exposure, lung function, systemic inflammation, and genotoxicity in peripheral blood mononuclear cells from firefighters before and after a work shift
}

Andersen, Maria Helena Guerra; Saber, Anne Thoustrup; Pedersen, Julie Elbæk; Pedersen, Peter Bøgh; Clausen, Per Axel; Løhr, Mille; Kermanizadeh, Ali; Loft, Steffen; Ebbeshøj, Niels E.; Hansen, Åse Marie Total number of authors:

14

Published in:

Environmental and Molecular Mutagenesis

Link to article, DOI:

10.1002/em.22193

Publication date:

2018

Document Version

Peer reviewed version

Link back to DTU Orbit

Citation (APA):

Andersen, M. H. G., Saber, A. T., Pedersen, J. E., Pedersen, P. B., Clausen, P. A., Løhr, M., Kermanizadeh, A., Loft, S., Ebbeshøj, N. E., Hansen, A. M., Kalevi Koponen, I., Nørskov, E. C., Vogel, U. B., \& Møller, P. (2018). Assessment of polycyclic aromatic hydrocarbon exposure, lung function, systemic inflammation, and genotoxicity in peripheral blood mononuclear cells from firefighters before and after a work shift. Environmental and Molecular Mutagenesis, 59(6), 539-548. https://doi.org/10.1002/em.22193

\section{General rights}

Copyright and moral rights for the publications made accessible in the public portal are retained by the authors and/or other copyright owners and it is a condition of accessing publications that users recognise and abide by the legal requirements associated with these rights.

- Users may download and print one copy of any publication from the public portal for the purpose of private study or research.

- You may not further distribute the material or use it for any profit-making activity or commercial gain

- You may freely distribute the URL identifying the publication in the public portal 
Assessment of polycyclic aromatic hydrocarbon exposure, lung function, systemic inflammation, and genotoxicity in peripheral blood mononuclear cells from firefighters before and after a work shift

Maria Helena Guerra Andersen ${ }^{\text {a.b }}$, Anne Thoustrup Saber ${ }^{\mathrm{b}}$, Julie Elbæk Pedersenc, Peter Bøgh Pedersen $^{\mathrm{d}}$, Per Axel Clausen ${ }^{\mathrm{b}}$, Mille Løhra ${ }^{\mathrm{a}}$, Ali Kermanizadehª, Steffen Loft ${ }^{\mathrm{a}}$, Niels Ebbehøj ${ }^{\mathrm{c}}$, Åse Marie Hansen ${ }^{\mathrm{b}, \mathrm{e}}$, Ismo Kalevi Koponen ${ }^{\mathrm{b}}$, Eva-Carina Nørskov ${ }^{\mathrm{d}}$, Ulla Vogel ${ }^{\mathrm{b}, \text { f*}^{*}}$, Peter Møller ${ }^{\mathrm{a}^{*}}$

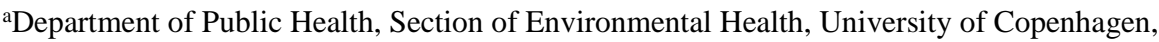
Øster Farimagsgade 5A, DK-1014 Copenhagen K, Denmark.

bThe National Research Centre for the Working Environment, Lersø Parkalle 105, DK-2100 Copenhagen Ø, Denmark.

cDepartment of Occupational and Environmental Medicine, Bispebjerg Hospital, Bispebjerg Bakke 23, DK-2400 Copenhagen NV, Denmark.

dDanish Technological Institute, Teknologiparken, Kongsvang Allé 29, DK-8000 Aarhus C, Denmark.

eDepartment of Public Health, Section of Social Medicine, University of Copenhagen, Øster Farimagsgade 5A, DK-1014 Copenhagen K, Denmark.

fDepartment of Micro- and Nanotechnology, Technical University of Denmark, DK-2800

Kgs, Lyngby, Denmark.

${ }^{*}$ Corresponding authors: aDepartment of Public Health, Section of Environmental Health, University of Copenhagen, Øster Farimagsgade 5A, DK-1014 Copenhagen K, Denmark, 
email: pemo@sund.ku.dk. ${ }^{\mathrm{b}}$ The National Research Centre for the Working Environment, Lersø Parkalle 105, DK-2100 Copenhagen Ø, Denmark, email: ubv@nrcwe.dk.

Running title: Biomarkers of exposure and effect after firefighter’s work shift

Key words: biomonitoring, ultrafine particles, 1-hydroxypyrene, oxidative DNA damage, comet assay 


\section{Abstract}

The International Agency for Research on Cancer has classified firefighting as possibly carcinogenic, although there are few mechanistic studies on genotoxicity in humans. We investigated exposure to polycyclic aromatic hydrocarbons (PAH), lung function, systemic inflammation and genotoxicity in peripheral blood mononuclear cells (PBMC) of $\underline{22}$ professional firefighters before and after a $24 \mathrm{~h}$ work shift. Twenty-two firefighters participated in the study. Exposure was assessed by measurements of particulate matter (PM), PAH levels on skin, urinary 1-hydroxypyrene (1-OHP) and self-reported occupational exposure to smoke. PM measurements indicated that use of personal protective equipment (PPE) effectively prevented inhalation exposure, but that exposure to PM occurred in situations when the team leader perceived the environment as safe and the self-contained breathing apparatuses were removed. The level of total PAH on the skin (back of the neck) was similar before and after the work shift. Fourteen firefighters reported work shift exposure to smoke. There was no difference in urinary excretion of 1-OHP comparing before and after the work shift, irrespectively of self-reported exposure to smoke. Post-shift, the subjects had reduced levels of oxidatively damaged DNA in PBMC, and increased plasma concentrations of cell adhesion molecules. The subjects reporting exposure to smoke during the work shift had a slightly decreased lung function, increased plasma concentrations of one cell adhesion molecule, and reduced levels of oxidatively damaged DNA in PBMC. Our results suggest that the firefighters were not exposed to PM while using PPE, but exposure occurred when PPE was not used. The work shift was not associated with increased levels of genotoxicity or decreased lung function, while increased levels of cell adhesion molecules in plasma were observed. 


\section{Introduction}

The International Agency for Research on Cancer (IARC) has evaluated occupational firefighting activity as possibly carcinogenic to humans (Group 2B), based on increased risk of testicular and prostate cancer as well as non-Hodgkin's lymphoma (IARC 2010). IARC segregated firefighting activities into different types of fire scenarios, including municipal, wildland, industrial, aviation, military and oil well fires. Firefighters can be exposed to different types of carcinogens, depending on the type of fuel that is being burnt. As such, "smoke" is a complex mixture that contains soot and numerous other substances, namely genotoxic compounds. IARC noted a lack of studies on genotoxicity in firefighters, which is a critical mechanism of carcinogenesis.

Previous studies on firefighters have focussed on genotoxic effects of polycyclic aromatic hydrocarbons (PAH). This is a group of genotoxic compounds that can form PAH-DNA adducts in cells (Phillips 2013). Pioneer studies showed the same level of PAH-DNA adducts in peripheral blood mononuclear cells (PBMC) from municipal firefighters and matched controls (Liou et al. 1989). Fire-fighting activity did not change PAH-DNA adduct levels $\underline{\text { in }}$ PBMC in wildland firefighters (Rothman et al. 1993). Likewise, volunteer firefighters had the same level of PAH-DNA adducts in PBMC before and after a work shift where they were exposed to plumes of smoke from oil well fires in Kuwait (Darcey et al. 1992). The collective results suggest a lack of PAH-DNA adducts, although this cannot be taken as evidence of lack of exposure or that smoke does not pose a genotoxic hazard to firefighters.

Oxidatively generated nucleobase lesions constitute a group of DNA lesions that are formed by oxidative stress and inflammation in cells or tissues (Moller et al. 2013). The most widely investigated lesion has been 8-oxoguanine, which is a pre-mutagenic nucleobase lesion (Cadet et al. 2012). Traditionally, 8-oxoguanine levels have been measured with chromatographic assays, whereas the formamidopyrimidine DNA glycosylase (Fpg)-modified comet assay has 
become the method of choice for this type of oxidatively damaged DNA. The comet assay can also be used to detect non-specific DNA lesions; these are typically called DNA strand breaks in order to distinguish them from the Fpg-sensitive sites. In a recent biomonitoring study of 53 conscripts under education as firefighters, firefighting was associated with increased levels of PAH on the skin, increased urinary excretion of 1-OHP and increased levels of oxidatively damaged DNA in PBMC (Andersen et al. 2017a). Municipal firefighters had increased levels of DNA strand breaks in PBMC after a firefighting episode at a chemical plant where they did not wear protective clothing or other safety provisions (Hengstler et al. 1995). Another study showed higher levels of DNA strand breaks in PBMC from firefighters as compared to controls, whereas the levels of Fpg-sensitive sites were similar in the two groups of subjects (Abreu et al. 2017). However, a controlled wood smoke exposure study showed unaltered levels of DNA strand breaks and Fpg-sensitive sites in PBMC (Forchhammer et al. 2012), whereas another study actually showed decreased levels of Fpg-sensitive sites and a tendency toward increased DNA repair activity after wood smoke exposure (Danielsen et al. 2008).

Inhalation of smoke particles may elicit pulmonary inflammation, which is considered to be an important mechanism for both lung cancer and systemic effects (IARC 2010). Low-grade systemic inflammation, i.e. elevated levels of C-reactive protein (CRP), serum amyloid protein (SAA), interleukin (IL), intracellular cell adhesion molecule 1 (ICAM-1) and vascular cell adhesion molecule 1 (VCAM-1) might occur from spill-over from pulmonary inflammation (Stone et al. 2016). In a recent biomonitoring study of 53 conscripts under education as firefighters, firefighting did not affect markers of systemic inflammation (IL8, IL6, ICRP, SAA, ICAM-1 or VCAM-1) but lowered heart rate variability and affected vascular flow (Andersen et al. 2017a; Andersen et al. 2017b), indicating effects of firefighting on the cardiovascular system. 
The aim of the present study was to investigate PAH exposure, lung function, systemic inflammation and DNA damage in circulating PBMC of firefighters after a day of work.

\section{Materials and methods}

\section{Subjects and study design}

Twenty-two male subjects were enrolled from a firefighter station in Greater Copenhagen Fire Department. In this station, firefighters had 24-h work shifts, followed by 3 days off prior to the next December (these are described as day 1, 2 and 3 in the results)(Table 1). The subjects male professional firefighters. Table I shows their characteristics by day group. The age of the subjects ranged from 39 to 59 years. The body mass index (BMI) was determined using selfreported information on weight and height and ranged from 22.2 to $31.3 \mathrm{~kg} / \mathrm{m}^{2}$ (seven subjects between 22.2 and 24.6, twelve subjects between 25.1 and 28.3 and two subjects between 30.4 and 31.3). From the 22 subjects, nine self-reported as never smokers, nine had a history of smoking and four reported being current smokers.

The design was a sequential study, where the subjects served as their own controls measured at two different time points: at the-start of the work shift (between 8 and 9 am) and at the end of the shift around $24 \mathrm{~h}$ later (between 7 and 8 am), ealledtermed "before” and "after" shift, respectively. All subjects had emergency calls relating to firefighting on their work shift.

The Danish Committee on Health Research Ethics of the Capital Region (H-15003862) approved the study and subjects provided written informed consent.

\section{Exposure assessment}


The exposure assessment had certain limitations as individual emergency calls were emergency situations,all different and impossible to predict. Thus, the assessment is intended tonly provides a description of the exposure situation rather than a detailed assessment of the exposure. The study was carried out at the time of year where fires occur most frequently in the greater Copenhagen area (personal communication with the fire department). We assessed the-The exposure to PM was evaluated by having a skilled researcher on call with the firefighter team during the three work shifts where biological samples were obtained from the firefighters. The assessment included measurements of the particle number concentration inside the mask of the firefighter, whose responsibility was to extinguish the fire, and other measurements at the scene of the emergency. The equipment encompassed a handheld ultrafine particle (UFP) counter DiSCmini (Testo, Titisee-Neustadt, Germany) with a tube into the mask, an UFP counter P-Trak (model 8525, TSI, USA) and an aerosol monitor DustTrak (DRX, model 8533, TSI, USA). PAH exposure was assessed by personal monitoring of 1-OHP in urine and PAH levels on the skin. The subjects filled completed a questionnaire where they were asked about their task in the teamresponsibilities at the scene of the fire and self-perception of exposure to smoke.

\section{Sample collection}

Samples of urine, blood and dermal wiping wipes collected before and after the work shift at the firefighter station. Urine was collected for the determination of 1-OHP. Urine was kept in cooling boxes until arrival at the laboratory and at $-20^{\circ} \mathrm{C}$ until analysis. Blood sampling was carried out to assess inflammatory markers (SAA, CRP, ICAM-1, VCAM-1, IL-6 and IL-8) and DNA damage in PBMC. Plasma for the ELISA analysis of the inflammatory markers, was prepared by 10 min centrifugation at $4000 \mathrm{rpm}$ (1780x g) of blood collected into EDTA-coated tubes (Becton Dickinson, $10 \mathrm{~mL}$ Vacutainer containing $18.0 \mathrm{mg}$
Commented [UBV2]: Anne gets a confirmation from the Brandvæsen

ATS: So far not possible to get a confirmation

Commented [AK3]: Is this necessary? 
$\mathrm{K}_{2}$ EDTA). The plasma samples were prepared at the firefighter station and transported to the

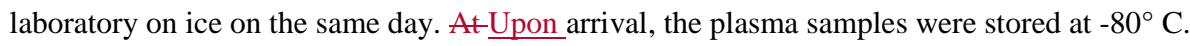
At the firefighting station, PBMC were isolated using Vacutainer Cell Preparation Tubes (Vacutainer® CPT Becton Dickinson A/S, Brøndby, Denmark). The PBMC were isolated before aby 20 min centrifugation at 1650x g. The PBMC were re-suspended in $3 \mathrm{~mL}$ ice-cold medium (RPMI with 10\% foetal bovine serum and 1\% Pen/Strep) and the samples were transported to the laboratory on ice in-on the same day where further sample preparation was performed. At arrival at the laboratory, the PBMC were separated by 15 min centrifugation at $300 \mathrm{x}$ g at $5^{\circ} \mathrm{C}$ and re-suspended in $3 \mathrm{~mL}$ RPMI medium with $10 \%$ foetal bovine serum and 1\% Pen/Strep. The same centrifugation procedure was repeated and the PBMC were-resuspended in freezing medium (RPMI with 50\% foetal bovine serum and 10\% DMSO). The PBMC were stored at $-80^{\circ} \mathrm{C}$ until analysis of DNA damage by the comet assay.

Dermal wiping of the neck was carried out to assess the PAH exposure on the skin. A skin area of approximately $3 \mathrm{~cm}$ x $6 \mathrm{~cm}$ on the back of the neck was wiped with an "Alkoholswab" (70\% isopropanol/water, Mediq Danmark A/S). The skin was wiped twice with the same wipe, first with one side of the wipe and then the other side. The operator wore nitrile gloves (TouchNTuff, 92-600, Ansell), which were changed for each wipe. The wipes were placed in $15 \mathrm{~mL}$ screw cap glass vials with foil-lined lid (Wheaton), which were, placed-kept in the dark and transported to the laboratory on the same day. The samples were stored at $-18^{\circ} \mathrm{C}$ until extraction and analysis. In these experiments, a skin area (back of the neck)-of nominally $18 \mathrm{~cm}^{2}$ was used in all calculations. During the campaigns, extracts of two blank wipes in screw cap glasses were analysed for each series of wipe samples. None of the individual PAHs were above the limit of detection (LOD) in any of the blanks. 
The extraction of PAH was carried out by covering the wipes with $6 \mathrm{~mL}$ cyclohexane in 10 $\mathrm{mL}$ glass vials and senicate-sonication for $30 \mathrm{~min}$ in an ultra-sonic bath (Branson 5200, output power $120 \mathrm{~W}$ at extraction of 25 samples at one time). One millilitre of the supernatant was transferred into a small glass vial and $30 \mu \mathrm{L}$ of internal standard solution $(10 \mathrm{ng} / \mu \mathrm{L})$ added. The extracts were stored at $-18^{\circ} \mathrm{C}$ until analysis. The extracts were analysed by gas chromatography and mass spectrometry (GC-MS) using a Bruker SCION TQ (Bruker Daltonics, Bremen, Germany). The analysis was carried out by injection of $1 \mu \mathrm{L}$ of the sample extract with a Bruker CP-8400 auto sampler to a programmable temperature vaporising (PTV) injector at $280^{\circ}$ into the column with a He flow of $1 \mathrm{~mL} / \mathrm{min}$. The column was $30 \mathrm{~m}$ x $0.25 \mathrm{~mm}$ with $0.25 \mu \mathrm{m}$ film thickness (VF-5MS, Agilent Technologies, US). The GC oven program was set at $70^{\circ} \mathrm{C}$ for $4 \mathrm{~min}$, ramp $1,10^{\circ} \mathrm{C} \min ^{-1}$ to $30^{\circ} \mathrm{C}$, ramp $2,45^{\circ} \mathrm{C} \min ^{-1}$ to $325^{\circ}$ hold for $7 \mathrm{~min}$ and transfer line and the source were kept at $275^{\circ} \mathrm{C}$. The MS was operated in scan mode (mass range m/z 50-500) in Electron Ionization (EI) and in Selected Ion Monitoring (SIM) for each PAH. $\mathrm{PAH}$ is the sum of the concentrations of naphthalene, acenaphthylene, acenaphthene, fluorene, phenanthrene, anthracene, fluoranthene, pyrene, benz(a)anthracene, chrysene, benzo(b)fluoranthene, benzo(k)fluoranthene, benzo(a)pyrene, dibenz(a,h)anthracene, indeno(1,2,3-cd)pyrene and benzo(g,h,i)perylene.

\section{Urinary 1-OHP analysis}

Reverse-phase HPLC was used for the measurement of 1-OHP in urine using athe previously published method (Hansen et al. 1993). Urinary creatinine was used to standardise for diuresis as performed in other studies (Hansen et al. 2008). We analysed a low (9.23 nmol/L) and a high (29.14 nmol/L) reference sample together with the samples to assess equivalence between different runs. 


\section{Lung function measurement}

The lung function was assessed using a Vitalograph S spirometer (Buckingham, United

Kingdom) measuring forced vital capacity (FVC) and forced expiratory volume after 1 second (FEV1). The equipment was calibrated before each testing session. All measurements were performed with the subjects standing and using a nose clip. Up to three measurements were taken to obtain reproducible tracings with the two highest FVC, FEV1 and FEV1/FVC.

\section{Inflammatory markers analysis in plasma}

The concentrations of soluble ICAM-1 (Cat. No. 560269) and VCAM-1 (Cat. No: 560427) were assessed in plasma with BD cytometric bead array system, utilising Accuri CFlow®Plus software (BD Bioscience) as described previously (Jensen et al. 2014). Plasma levels of SAA and CRP were determined by Enzyme-linked Immunosorbant assay (ELISA) from Invitrogen (Carlsbad, CA, USA) and IBL International GMBH (Hamburg, Germany), respectively, as described previously (Madsen et al. 2016). Plasma levels of IL-6 and IL-8 were determined by ELISA from BD Biosciences (cat. No. 555244 and Cat. No.555220) according to the manufacturer’s specifications.

\section{DNA damage analysis in PBMC}

The levels of DNA strand breaks and Fpg-sensitive sites were detected by the comet assay as described previously (Lohr et al. 2015). Briefly, PBMC were embedded in 0.75\% low-melting point agarose (Sigma-Aldrich A/S, Brøndby, Denmark) on GelBond films (Lonza Copenhagen Aps, Vallenbæk Strand, Denmark) and lysed (1 \% Triton X-100, $2.5 \mathrm{M} \mathrm{NaCl}$, $100 \mathrm{mM} \mathrm{Na}_{2} \mathrm{EDTA}, 10 \mathrm{mM}$ Tris, $\mathrm{pH}=10$ ) overnight at $4^{\circ} \mathrm{C}$. The Gelbond films were washed three times for $5 \mathrm{~min}$ in endonuclease buffer (40 mM HEPES, $0.1 \mathrm{M} \mathrm{KCl}, 0.5 \mathrm{mM} \mathrm{Na} 2 \mathrm{EDTA}$, $200 \mu \mathrm{g} / \mathrm{mL}$ bovine serum albumin, $\mathrm{pH}=8$ ). Subsequently, the nuclei were incubated for 45 
min with Fpg at $37^{\circ} \mathrm{C}$. The Fpg enzyme was a gift from Professor Andrew Collins (University of Oslo, Norway). Thereafter, the Gelbond films were immersed in an alkaline solution (300 $\mathrm{mM} \mathrm{NaOH}, 1 \mathrm{mM} \mathrm{Na} 2 \mathrm{EDTA}, \mathrm{pH}>13$ ) for $40 \mathrm{~min}$ and subsequently subjected to electrophoresis for $20 \mathrm{~min}$ at $0.83 \mathrm{~V} / \mathrm{cm}$ (cathode to anode) and $300 \mathrm{~mA}$. After electrophoresis the Gelbonds were washed 3 times for 5 min in Tris buffer (0.4 M Tris-HCl, $\mathrm{pH}=7.5)$, rinsed with milliQ water and dried in 96\% ethanol. The nuclei were scored using an Olympus fluorescence microscope at 40x magnification with visual inspection after staining with YOYO-1 in PBS (Molecular Probes, Eugene, OR, USA). The two samples from each subject were coded and analysed simultaneously in order to minimise inter-assay variation. In addition, each batch of comet assay experiments included samples from the three workdayshifts in order to control for inter-day experimental variation. We analysed 100 comets per slide and there were four slides for each sample, corresponding to a total number of 400 nuclei. The slides had been prepared in duplicates on two different assay runs (including different electrophoresis). The nuclei were scored by visual classification based on a fiveclass scoring system (arbitrary score range: 0-400) as previously described (Moller et al. 2004). We hadAdditionally, assay control samples were added in each experiments (corresponding to each electrophoresis) that consisted of $\mathrm{KBrO}_{3}$ exposed THP-1 cells (5 mM for $1 \mathrm{~h}$ at $37^{\circ} \mathrm{C}$ ). The number of Fpg-sensitive sites was obtained as the difference in scores of parallel slides incubated with and without Fpg. These scores were transformed to lesions per $10^{6}$ base pairs (bp) by means of a calibration curve based on induction of DNA strand breaks by ionising radiation, which has a known yield. We used an investigator-specific conversion factor of 0.01989 lesions $/ 10^{6}$ bp per score in 0-100 range (Lohr et al. 2015), based on the assumption that an average molecular weight of a DNA bp is 650 Dalton and 1 Gy yields 0.29 breaks per $10^{9}$ Dalton DNA (Forchhammer et al. 2010). 


\section{Statistical analysis}

The results were analysed by mixed effects models with either self-reported occupational smoke exposure or work shift as predictors and outcome biomarkers nested in each subjects.

Effects are reported as percent changes and 95\% confidence interval (95\% CI) based on coefficient and intercepts in the mixed effects models.

\section{Results}

\section{Exposure assessment}

During all three bio-monitoring days Each day had a number of the emergency calls that were false alarms or incidencesassistances that did not entail suppression of fires (e.g. flooding of a basement in day 3). A Belowe describe thedescription of -situations on each of the monitoring days-that entailed particle exposure is provided below. The supplement material also includes a more detailed narrative of the observations at the fire scene as well as timeseries measurements of the PM exposure during the fire suppression activities. It should be noted that each firefighter in a team has specific tasks-responsibilities at the scene of fire and individualspecific tasks may or may not entail exposure to smoke.

All firefighters reported exposure to smoke on the day 1 , when they were called to both an outdoor fire in a car and a fire in an electrical installation in a basement. On the second day, the firefighters reported little firefighting activity. The observer noted that the firefighters did not wear PPE with self-contained breathing apparatus during the inspection of an indoor suspected fire scene. The on-site measurements of UFPs peaked at number concentration of $\approx 90.000 \# / \mathrm{cm}^{3}$ (day 2). The day 3 included a small fire in a waste container and a large fire that was initiated in a container and later spread to an apartment building. For Unfortunately, due to logistic reasons, unfortunately, we do not have on-site measurements for the last event. 
The majority of firefighters reported exposure to smoke in day 3 (6 out of 7 firefighters, table I). In addition to particle exposure from fires, our measurements suggested that a significant UFP exposure resulted originated from a call to a flooding incident in day 3 from a damaged toiletin a home of a heavy smoker (i.e. the objective number concentration measurements peaked up secondary or tertiary smoke exposure).

Overall, the exposure measurements showed that the use of PPE effectively prevented inhalation exposure to particles. Moreover, the exposure measurements did not demonstrate high exposure to PM on the assessed work shift events.

The skin concentration of $\Sigma \mathrm{PAH}$ before work shift was measured on all 22 subjects and was

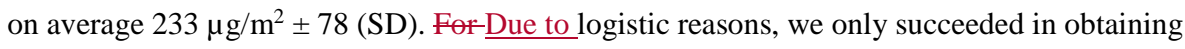
skin wipes immediately after returning to the station after the emergency call for 9 subjects, 7 from day 1, 1 from day 2, and 1 from day 3. For these 9 subjects, the skin concentration of $\Sigma$ PAH before the work shift was on average $179 \mu \mathrm{g} / \mathrm{m}^{2} \pm 95$ (SD), and after work shift181 $\mu \mathrm{g} / \mathrm{m}^{2} \pm 60$ (SD) after the shift.

The concentrations of 1-OHP in urine for each measurement day are-is reported in table 1. The subjects in day 2 had somewhat lower 1-OHP excretion levels as compared to the other days. The reasons for this difference is not clear. However, pre-samples for subjects in day 2 were obtained at the same time as post-samples for subjects in day 1. Likewise, post-samples for subjects in day 2 were obtained at the same time as pre-samples from subjects in day 3. The highest concentrations of 1-OHP from the subjects in day 2 were higher than the lowest concentrations from the subjects in days 1 and 3. Thus, the difference in 1-OHP concentrations between days does not appear to be due to the sampling procedure. The levels

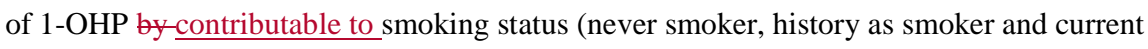
smoker) were not different. 


\section{Biological measurements}

Table II shows the mean levels of biomarkers in samples from all firefighters obtained before and after the work shifts. The results were further stratified according to self-reported exposure to smoke (table 3).

Effect sizes are reported in table IV as the difference related to the work period (i.e. difference in biomarkers between before and after the work shift) or self-reported smoke exposure. In general, there was no difference in levels of urinary 1-OHP expression between before and after the work shift and self-reported exposure to smoke was not associated with altered 1OHP excretion. The subjects had lower levels of Fpg-sensitive sites in PBMC after work shift compared to before work shift, whereas the levels of ICAM-1 and VCAM-1 were increased. No effects on SAA and CRP were observed. The self-reported smoke exposure during the work shift was associated with decreased levels of FVC1/FVC and Fpg-sensitive sites, whereas the VCAM-1 levels were increased.

The levels of IL-6 and IL-8 were generally below the limits of detection of the assays (2.34 and $1.56 \mathrm{pg} / \mathrm{ml}$, respectively).

\section{Discussion}

Measurements of UFP inside the mask of one firefighter per during the work shift showed that use of PPE prevented inhalation exposure to PM during firefighting, and that exposure occurred when firefighters had taken off the mask (supplementary material, figure S2 and S5). Biological measurements were performed before and after one work shift, where the study subjects had not been at work the 3 preceding days. The firefighters had increased plasma levels of cell adhesion molecules and lowered levels of genotoxicity in PBMC after the work 
shift compared to pre-shift values. Slightly decreased lung function measurements were seen in statistical models with self-reported occupational smoke exposure as predictor.

Firefighting encompasses many different job-titless which result in varying different type and intensity of exposure. Thus, it is not surprising the subjects reported differences in exposure to smoke. In narrative, the firefighters described their tasks at the sceneduring a fire emergency as "fire suppression”, "surveillance of the fire after first suppression”, "in charge of the ladder”, “water supply” and "team leader”. The limited number of subjects precludes any the possibility to distinguish between the tasks with respect to smoke exposure. Skin exposure level of $\Sigma \mathrm{PAH}$ before and after work shifts was not significantly different (179-181 $\mu \mathrm{g} / \mathrm{m}^{2}$ ) and was on the same average level as observed previously for conscripts in control periods $\left(151 \mu \mathrm{g} / \mathrm{m}^{2} \pm 98\right.$ (SD)) but in the lower end of the range after exposure (118-625 $\mu \mathrm{g} / \mathrm{m}^{2}$ ) (Andersen et al. 2017a). In the present study, the subjects had hadthree days off prior to the work shift. On the three different biomonitoring days, pre-shift 1-OHP values varied from 0.24 to $0.72 \mu \mathrm{mol} / \mathrm{mol}$ creatinine. Background levels of 1-OHP are influenced by various exposure pathways of PAH including inhalation (smoking, air pollution), skin exposure, and dietary intake of PAH (Jongeneelen 2001). In a Danish study, non-smoking mail carriers had a urinary 1- OHP level of $0.1 \mu \mathrm{mol} / \mathrm{mol}$ creatinine (CI: 0.07-0.13) and nonsmoking bus drivers had $0.19 \mu \mathrm{mol} / \mathrm{mol}$ creatinine (CI: 0.16-0.21) (Hansen et al. 2004). This indicates that the firefighters had higher urinary 1-OHP excretion levels than non-smoking mail carriers. Background or reference levels of $0.24 \mu \mathrm{mol} / \mathrm{mol}$ creatinine for non-smokers and $0.76 \mu \mathrm{mol} / \mathrm{mol}$ creatinine have been suggested (Jongeneelen 2001). The observed postshift 1-OHP levels of 0.28-0.98 $\mu \mathrm{mol} / \mathrm{mol}$ creatinine are below the proposed no-observed genotoxic effect level of $1.0 \mu \mathrm{mol} / \mathrm{mol}$ creatinine (Jongeneelen 2014).

The firefighters had slightly better lung function as compared to the general population at their age (i.e. higher values than 100 for the FVC\% and FEV1\% measurements), which is 
most likely due to the work-related physical exercise. However, there were also slightly decreased levels of FEV1/FVC after the work shift, indicating a modest constriction of the conductive airways after exposure to smoke. The FEV1/FVC ratio is the proportion of the vital capacity that a person is able to expire in the first second of forced expiration. Normal levels are approximately $80 \%$ and lower levels might be an indication of obstructive lung disease. We regard the lung function measurements as demonstrating demonstrative of subclinical and reversible alterations. The observations mainly show a regression of the lung function in the firefighters toward the lung function in other people with the same age. Interestingly, we observed a lower level of Fpg-sensitive sites in PBMC in the post-shift samples as compared to pre-shift samples. This is at odds with the expected effect, i.e. increased level of DNA damage, although it is not an-unprecedented and similar to a response after exposure to wood smoke. In a previous study ${ }_{2}$ we observed a decreased level of Fpgsensitive sites in PBMC at $21 \mathrm{~h}$ after a short-term (3 h) exposure to wood smoke was observed (Danielsen et al. 2008). Fpg-sensitive sites are typically repaired with a half-life of approximately $6 \mathrm{~h}$ in cell cultures after exposure to PM (Danielsen et al. 2009). A similar removal rate of Fpg-sensitive sites was observed in lung tissue after topical X-ray irradiation (Risom et al. 2003). We have recently performed a similar human exposure study on 53 nonsmoking conscripts undergoing a 3 day training course to become firefighters (Andersen et al. 2017a). Among these conscripts, firefighting was associated with increased PAH levels on skin, increased urinary 1-OHP excretion and increased levels of Fpg-sensitive sites in PBMC. A previous study reported similar levels of urinary excretion of 8-oxo-7,8-dihydro-2'deoxyguanosine (8-oxodG) in firefighters who had been exposed at work as in unexposed workers (Hong et al. 2000). However, the analysis was based on antibody-based detection of 8-oxodG, which is a highly unspecific and unreliable measurement of this lesion (Barregard et al. 2013). Nevertheless, a study on wildland firefighters also showed no difference in urinary 
levels of 8-oxodG, measured with a reliable method, between pre- and post-shift samples after an episode of prescribed burns (Adetona et al. 2013). It is generally acknowledged that 8oxodG in urine does not originate from OGG1-mediated repair processes, whereas it is considered to be a biomarker of whole-body oxidative stress that has predictive value of lung and breast cancer risk (Loft and Moller 2006; Loft et al. 2006; Loft et al. 2013).

A recent pooled analysis of case-control studies of firefighters, encompassing approximately 15,000 cases and 17,500 controls found no association between with lung cancer risk with or without adjustment for smoking (Bigert et al. 2016). IARC has classified exposures to diesel engine exhaust and PM in outdoor air as carcinogenic (IARC 2014; IARC 2016). In contrast to this study in which no to the lack of genotoxicity is noted in the present study on firefighters, there are many numerous studies that have demonstrated associations between air pollution exposure and elevated levels of DNA adducts and oxidatively damaged DNA in PBMC and leukocytes from humans (Moller and Loft 2010; Demetriou et al. 2012). PM samples from different locations have shown concentration-dependent increases DNA damage in cell cultures (Moller et al. 2014). These effects of air pollution particles on oxidation damage to DNA in PBMC are typically observed within hours of controlled inhalation exposure (Vinzents et al. 2005).

We found that plasma levels of soluble ICAM-1 and VCAM-1 were increased post-shift compared to pre-shift. These markers are considered to be markers of endothelial cell activation (Ballantyne and Entman 2002). Endothelial cells express these cell adhesion molecule on the membrane to bind inflammatory cells and assist the migration through the endothelium. ICAM-1 and VCAM-1 can be sequestered from plasma or translocated to the membrane from the cytoplasm. Thus, decreased levels of ICAM-1 and VCAM-1 in plasma may indicate increased binding to endothelial cells, whereas high plasma concentrations may indicate a higher turn-over of soluble cell adhesion molecules due to endothelial cell damage. 
Thus, soluble ICAM-1 and VCAM-1 levels may be increased (typically long-term exposures) or decreased (typically short-term exposures) in plasma, depending on the time-window between exposure (and endothelial cell activation) and blood sampling. Epidemiological studies have shown positive associations between long-term air pollution exposure and soluble ICAM-1 and VCAM-1 levels (Madrigano et al. 2010; Alexeeff et al. 2011; Chiu et al. 2016; Pope et al. 2016). We recently reported no effect on ICAM-1 and VCAM-1 levels of a 3 day firefighting training course for conscripts (Andersen et al. 2017a). Short-term controlled exposure to wood smoke was associated with decreased levels of soluble ICAM-1 in plasma (Muala et al. 2015). A one-week exposure also decreased plasma levels of ICAM-1 and VCAM-1 (Jensen et al. 2014). However, increased levels of ICAM-1 and VCAM-1 were observed in plasma from wild-land firefighters after exposure to wood smoke during prescribed burns. The differences in response to urban air pollution and wood smoke may be related to the physicochemical characteristics of PM, although the time period between exposure and blood sampling is also important.

This study hadhas several limitations. Firstly, the study-subjects only had 3 days without work prior to the biomonitoring day. This may result in elevated levels of biomarkers in the pre-shift samples. Secondly, there is a risk of exposure misclassification. It was not possible to objectively stratify| the subjects according to exposure status as we only assessed personal exposure of a few selected firefighters and only during part of their work day, although we assessed urinary excretion of 1-OHP in all subjects of the study. All subjects may to some extent have been exposed to PM as the exposure measurements in the inhalation zone of a few firefighters showed exposure to PM under conditions the team leader considered sufficiently safe to not use mask. The measurement of 1-OHP is an objective measurement, but it only captures pyrene exposure and also reflects other exposures such as grilled or smoked food. A non-differential exposure misclassification tends to drive effect estimates toward null. 
Another limitation is the sequential study design with samples obtained before and after the work shift. This design does not control for period effects, which are unrelated to the exposure. For instance, we have not controlled for pre-work exposure to PAH from food or indoor combustion sources such as candle lights. Lastly, the number of subjects was small, thus limiting the statistical power.

In conclusion, this study indicates that firefighters are not exposed to PM when firefighting while wearing PPE, but exposure may occur in situations that arethey considered as safe. Firefighting did not increase the PAH levels on the skin or 1-OHP concentrations in urine. The work shift was not associated with increased levels of genotoxicity or decreased lung function, while increased levels of cell adhesion molecules in plasma was observed.

\section{Statement of Author Contributions:}

MHGA analysed the results and wrote the draft of the manuscript. ATS designed and coordinated the study, supervised the data analysis and the writing of the manuscript. JEP collected and reported the lung function and questionnaires data and the data from the questionnaires. PBP measured and reported the exposure. PAC supervised the collection, analysis and report of the dermal PAH data. ML performed the DNA data analysis. AL $\underline{\mathrm{AK}}$ supervised and reported on the ICAM-1 and VCAM-1 analysis. SL designed the study and was a major contributor in the analysis and interpretation of results. NE designed the study and contributed to the analysis and interpretation of results. AMH supervised the analysis and report of 1-OHP. IKK assisted in the exposure assessment. ECN contributed to the interpretation of results. UV designed and supervised the study and was a major contributor in the writing of the manuscript. PM designed and supervised the study and was a major contributor to the analysis, interpretation and writing of the manuscript. All authors have read and approved the final manuscript._Acknowledgments: 
The technical assistance from Anne Abiltrup, Ulla Tegner, Inge Christiansen, Vivi KofoedSørensen and Lisbeth Carlsen is gratefully acknowledged. We have established a reference group which includes stakeholders from e.g. fire brigades, trade unions and The Danish Emergency Management Agency. We thank the reference group for their involvement in the overall study design. A special thanks to the Greater Copenhagen Fire Department where the measurements took place. We are also grateful to the study subjectsfirefighters for the considerable time and willingness put into thisin being involved in this study.

Funding: This work was supported by The Danish Working Environment Research Fund (BIOBRAND, grant 34-2014-09 / 20140072567, Danish Centre for Nanosafety, grant 20110092173/3 and Danish Centre for Nanosafety II).

Competing financial interests: The authors claim no competing financial interests.

\section{References}

Abreu A, Costa C, Pinho ESS, Morais S, do Carmo Pereira M, Fernandes A, Moraes de Andrade V, Teixeira JP, Costa S. 2017. Wood smoke exposure of Portuguese wildland firefighters: DNA and oxidative damage evaluation. J Toxicol Environ Health A:1-9.

Adetona O, Zhang JJ, Hall DB, Wang JS, Vena JE, Naeher LP. 2013. Occupational exposure to woodsmoke and oxidative stress in wildland firefighters. Sci Total Environ 449:269-275.

Alexeeff SE, Coull BA, Gryparis A, Suh H, Sparrow D, Vokonas PS, Schwartz J. 2011. Medium-term exposure to traffic-related air pollution and markers of inflammation and endothelial function. Environ Health Perspect 119(4):481-486.

Andersen MH, Saber AT, Clausen PA, Pedersen JE, Lohr M, Kermanizadeh A, Loft S, Ebbehoj N, Hansen AM, Pedersen PB, Koponen IK, Norskov EC, Moller P, Vogel U. 2017a. Association between polycyclic aromatic hydrocarbons exposure and peripheral blood mononuclear cell DNA damage in human volunteers during fire extinction exercises. Mutagenesis in press.

Andersen MHG, Saber AT, Pedersen PB, Loft S, Hansen AM, Koponen IK, Pedersen JE, Ebbehoj N, Norskov EC, Clausen PA, Garde AH, Vogel U, Moller P. 2017b. Cardiovascular health effects following exposure of human volunteers during fire extinction exercises. Environ Health 16(1):96.

Ballantyne CM, Entman ML. 2002. Soluble adhesion molecules and the search for biomarkers for atherosclerosis. Circulation 106(7):766-767. 
Barregard L, Moller P, Henriksen T, Mistry V, Koppen G, Rossner P, Jr., Sram RJ, Weimann A, Poulsen HE, Nataf R, Andreoli R, Manini P, Marczylo T, Lam P, Evans MD, Kasai H, Kawai K, Li YS, Sakai K, Singh R, Teichert F, Farmer PB, Rozalski R, Gackowski D, Siomek A, Saez GT, Cerda C, Broberg K, Lindh C, Hossain MB, Haghdoost S, Hu CW, Chao MR, Wu KY, Orhan H, Senduran N, Smith RJ, Santella RM, Su Y, Cortez C, Yeh S, Olinski R, Loft S, Cooke MS. 2013. Human and methodological sources of variability in the measurement of urinary 8-oxo-7,8-dihydro-2'-deoxyguanosine. Antioxid Redox Signal 18(18):2377-2391.

Bigert C, Gustavsson P, Straif K, Taeger D, Pesch B, Kendzia B, Schuz J, Stucker I, Guida F, Bruske I, Wichmann HE, Pesatori AC, Landi MT, Caporaso N, Tse LA, Yu IT, Siemiatycki J, Lavoue J, Richiardi L, Mirabelli D, Simonato L, Jockel KH, Ahrens W, Pohlabeln H, Tardon A, Zaridze D, Field JK, t Mannetje A, Pearce N, McLaughlin J, Demers P, Szeszenia-Dabrowska N, Lissowska J, Rudnai P, Fabianova E, Stanescu Dumitru R, Bencko V, Foretova L, Janout V, Boffetta P, Peters S, Vermeulen R, Kromhout H, Bruning T, Olsson AC. 2016. Lung Cancer Among Firefighters: Smoking-Adjusted Risk Estimates in a Pooled Analysis of CaseControl Studies. J Occup Environ Med 58(11):1137-1143.

Cadet J, Loft S, Olinski R, Evans MD, Bialkowski K, Richard Wagner J, Dedon PC, Moller P, Greenberg MM, Cooke MS. 2012. Biologically relevant oxidants and terminology, classification and nomenclature of oxidatively generated damage to nucleobases and 2deoxyribose in nucleic acids. Free Radic Res 46(4):367-381.

Chiu YH, Garshick E, Hart JE, Spiegelman D, Dockery DW, Smith TJ, Laden F. 2016. Occupational vehicle-related particulate exposure and inflammatory markers in trucking industry workers. Environ Res 148:310-317.

Danielsen PH, Brauner EV, Barregard L, Sallsten G, Wallin M, Olinski R, Rozalski R, Moller P, Loft S. 2008. Oxidatively damaged DNA and its repair after experimental exposure to wood smoke in healthy humans. Mutat Res 642(1-2):37-42.

Danielsen PH, Loft S, Kocbach A, Schwarze PE, Moller P. 2009. Oxidative damage to DNA and repair induced by Norwegian wood smoke particles in human A549 and THP-1 cell lines. Mutat Res 674(1-2):116-122.

Darcey DJ, Everson RB, Putman KL, Randerath K. 1992. DNA adducts and exposure to burning oil. Lancet 339(8791):489.

Demetriou CA, Raaschou-Nielsen O, Loft S, Moller P, Vermeulen R, Palli D, Chadeau-Hyam M, Xun WW, Vineis P. 2012. Biomarkers of ambient air pollution and lung cancer: a systematic review. Occup Environ Med 69(9):619-627.

Forchhammer L, Johansson C, Loft S, Moller L, Godschalk RW, Langie SA, Jones GD, Kwok RW, Collins AR, Azqueta A, Phillips DH, Sozeri O, Stepnik M, Palus J, Vogel U, Wallin H, Routledge MN, Handforth C, Allione A, Matullo G, Teixeira JP, Costa S, Riso P, Porrini M, Moller P. 2010. Variation in the measurement of DNA damage by comet assay measured by the ECVAG inter-laboratory validation trial. Mutagenesis 25(2):113-123.

Forchhammer L, Moller P, Riddervold IS, Bonlokke J, Massling A, Sigsgaard T, Loft S. 2012. Controlled human wood smoke exposure: oxidative stress, inflammation and microvascular function. Part Fibre Toxicol 9:7.

Hansen AM, Mathiesen L, Pedersen M, Knudsen LE. 2008. Urinary 1-hydroxypyrene (1-HP) in environmental and occupational studies--a review. Int J Hyg Environ Health 211(5-6):471503.

Hansen AM, Poulsen OM, Christensen JM, Hansen SH. 1993. Determination of 1-hydroxypyrene in human urine by high-performance liquid chromatography. J Anal Toxicol 17(1):38-41.

Hansen AM, Wallin H, Binderup ML, Dybdahl M, Autrup H, Loft S, Knudsen LE. 2004. Urinary 1hydroxypyrene and mutagenicity in bus drivers and mail carriers exposed to urban air pollution in Denmark. Mutat Res 557(1):7-17. 
Hengstler JG, Fuchs J, Bolm-Audorff U, Meyer S, Oesch F. 1995. Single-strand breaks in deoxyribonucleic acid in fire fighters accidentally exposed to o-nitroanisole and other chemicals. Scand J Work Environ Health 21(1):36-42.

Hong YC, Park HS, Ha EH. 2000. Influence of genetic susceptibility on the urinary excretion of 8hydroxydeoxyguanosine of firefighters. Occup Environ Med 57(6):370-375.

IARC. 2010. Painting, firefighting, and shiftwork. In: International Agency for Research on Cancer, editor. Monographs on the Evaluation of the Carcinogenic Risks to Humans vol 98. p 9-764.

IARC. 2014. Diesel and gasoline engine exhausts and some nitroarenes. In: Cancer IAfRo, editor. Monographs on the Evaluation of the Carcinogenic Risks to Humans, vol 105. p 9-699.

IARC. 2016. Outdoor air pollution. In: Cancer IAfRo, editor. Monographs on the Evaluation of the Carcinogenic Risks to Humans vol 109. p 9-444.

Jensen A, Karottki DG, Christensen JM, Bonlokke JH, Sigsgaard T, Glasius M, Loft S, Moller P. 2014. Biomarkers of oxidative stress and inflammation after wood smoke exposure in a reconstructed Viking Age house. Environ Mol Mutagen 55(8):652-661.

Jongeneelen FJ. 2001. Benchmark guideline for urinary 1-hydroxypyrene as biomarker of occupational exposure to polycyclic aromatic hydrocarbons. Ann Occup Hyg 45(1):3-13.

Jongeneelen FJ. 2014. A guidance value of 1-hydroxypyrene in urine in view of acceptable occupational exposure to polycyclic aromatic hydrocarbons. Toxicol Lett 231(2):239-248.

Liou SH, Jacobson-Kram D, Poirier MC, Nguyen D, Strickland PT, Tockman MS. 1989. Biological monitoring of fire fighters: sister chromatid exchange and polycyclic aromatic hydrocarbonDNA adducts in peripheral blood cells. Cancer Res 49(17):4929-4935.

Loft S, Moller P. 2006. Oxidative DNA damage and human cancer: need for cohort studies. Antioxid Redox Signal 8(5-6):1021-1031.

Loft S, Olsen A, Moller P, Poulsen HE, Tjonneland A. 2013. Association between 8-oxo-7,8-dihydro2'-deoxyguanosine excretion and risk of postmenopausal breast cancer: nested case-control study. Cancer Epidemiol Biomarkers Prev 22(7):1289-1296.

Loft S, Svoboda P, Kasai H, Tjonneland A, Vogel U, Moller P, Overvad K, Raaschou-Nielsen O. 2006. Prospective study of 8-oxo-7,8-dihydro-2'-deoxyguanosine excretion and the risk of lung cancer. Carcinogenesis 27(6):1245-1250.

Lohr M, Jensen A, Eriksen L, Gronbaek M, Loft S, Moller P. 2015. Age and metabolic risk factors associated with oxidatively damaged DNA in human peripheral blood mononuclear cells. Oncotarget 6(5):2641-2653.

Madrigano J, Baccarelli A, Wright RO, Suh H, Sparrow D, Vokonas PS, Schwartz J. 2010. Air pollution, obesity, genes and cellular adhesion molecules. Occup Environ Med 67(5):312-317.

Madsen AM, Thilsing T, Baelum J, Garde AH, Vogel U. 2016. Occupational exposure levels of bioaerosol components are associated with serum levels of the acute phase protein Serum Amyloid A in greenhouse workers. Environ Health 15:9.

Moller P, Danielsen PH, Jantzen K, Roursgaard M, Loft S. 2013. Oxidatively damaged DNA in animals exposed to particles. Crit Rev Toxicol 43(2):96-118.

Moller P, Danielsen PH, Karottki DG, Jantzen K, Roursgaard M, Klingberg H, Jensen DM, Christophersen DV, Hemmingsen JG, Cao Y, Loft S. 2014. Oxidative stress and inflammation generated DNA damage by exposure to air pollution particles. Mutat Res Rev Mutat Res 762:133-166.

Moller P, Friis G, Christensen PH, Risom L, Plesner G, Kjaersgaard J, Vinzents P, Loft S, Jensen A, Tved M. 2004. Intra-laboratory comet assay sample scoring exercise for determination of formamidopyrimidine DNA glycosylase sites in human mononuclear blood cell DNA. Free Radic Res 38(11):1207-1214. 
Moller P, Loft S. 2010. Oxidative damage to DNA and lipids as biomarkers of exposure to air pollution. Environ Health Perspect 118(8):1126-1136.

Muala A, Rankin G, Sehlstedt M, Unosson J, Bosson JA, Behndig A, Pourazar J, Nystrom R, Pettersson E, Bergvall C, Westerholm R, Jalava PI, Happo MS, Uski O, Hirvonen MR, Kelly FJ, Mudway IS, Blomberg A, Boman C, Sandstrom T. 2015. Acute exposure to wood smoke from incomplete combustion--indications of cytotoxicity. Part Fibre Toxicol 12:33.

Phillips DH. 2013. On the origins and development of the (32)P-postlabelling assay for carcinogenDNA adducts. Cancer Lett 334(1):5-9.

Pope CA, 3rd, Bhatnagar A, McCracken JP, Abplanalp W, Conklin DJ, O'Toole T. 2016. Exposure to Fine Particulate Air Pollution Is Associated With Endothelial Injury and Systemic Inflammation. Circ Res 119(11):1204-1214.

Risom L, Moller P, Vogel U, Kristjansen PE, Loft S. 2003. X-ray-induced oxidative stress: DNA damage and gene expression of HO-1, ERCC1 and OGG1 in mouse lung. Free Radic Res 37(9):957-966.

Rothman N, Poirier MC, Haas RA, Correa-Villasenor A, Ford P, Hansen JA, O'Toole T, Strickland PT. 1993. Association of PAH-DNA adducts in peripheral white blood cells with dietary exposure to polyaromatic hydrocarbons. Environ Health Perspect 99:265-267.

Stone V, Miller MR, Clift MJ, Elder A, Mills NL, Moller P, Schins RP, Vogel U, Kreyling WG, Jensen KA, Kuhlbusch TA, Schwarze PE, Hoet P, Pietroiusti A, De Vizcaya-Ruiz A, BaezaSquiban A, Tran CL, Cassee FR. 2016. Nanomaterials vs Ambient Ultrafine Particles: an Opportunity to Exchange Toxicology Knowledge. Environ Health Perspect.

Vinzents PS, Moller P, Sorensen M, Knudsen LE, Hertel O, Jensen FP, Schibye B, Loft S. 2005. Personal exposure to ultrafine particles and oxidative DNA damage. Environ Health Perspect 113(11):1485-1490. 
Table I - Characteristics of the subjects

\begin{tabular}{|c|c|c|c|c|}
\hline Characteristic & Day $1(n=7)$ & Day $2(n=8)$ & Day $3(n=7)$ & Total $(n=22)$ \\
\hline Age (years) & $50.9 \pm 6.8$ & $51.9 \pm 5.6$ & $52.4 \pm 6.9$ & $51.7 \pm 6.2$ \\
\hline BMI $\left(\mathrm{kg} / \mathrm{m}^{2}\right)^{\mathrm{a}}$ & $24.2 \pm 0.9$ & $27.0 \pm 3.3$ & $26.8 \pm 2.1$ & $26.8 \pm 2.6$ \\
\hline Smoker (yes/no) ${ }^{\mathrm{a}}$ & $1 / 6$ & $1 / 7$ & $2 / 5$ & $4 / 18$ \\
\hline ETS (yes/no) $)^{\mathrm{a}, \mathrm{b}}$ & $1 / 5$ & $1 / 6$ & $1 / 4$ & $3 / 15$ \\
\hline $\begin{array}{c}\text { Fire smoke } \\
\text { exposure (yes/no) }\end{array}$ & $7 / 0$ & $1 / 7$ & $6 / 1$ & $14 / 8$ \\
\hline
\end{tabular}

BMI, body mass index; ETS, environmental tobacco smoke. Values are number or mean and standard deviation.

${ }^{\text {a }}$ Self-reported information.

${ }^{\mathrm{b}}$ ETS among non-smokers. 
Table II - Levels of outcome markers before and after the 24-h work shift (mean \pm standard deviation) in 22 firefighters.

\begin{tabular}{|c|c|c|c|c|}
\hline Outcome & Day $1(n=7)$ & Day $2(n=8)$ & Day $3(n=7)$ & Total $(n=22)$ \\
\hline$\Sigma$ PAH before $\left(\mu \mathrm{g} / \mathrm{m}^{2}\right)$ & $132.8 \pm 17.0$ & $301.8 \pm 37.6$ & $253.2 \pm 32.4$ & $232.5 \pm 78.4$ \\
\hline$\Sigma$ PAH after $^{\mathrm{a}}\left(\mu \mathrm{g} / \mathrm{m}^{2}\right)$ & $155.6 \pm 16.8$ & $329.0 \pm \mathrm{NA}$ & $213.0 \pm \mathrm{NA}$ & $181.2 \pm 60.4$ \\
\hline $\begin{array}{l}\text { 1-OHP before ( } \mu \mathrm{mol} / \mathrm{mol} \\
\text { creatinine) }\end{array}$ & $0.72 \pm 0.62$ & $0.24 \pm 0.10$ & $0.66 \pm 0.58$ & $0.52 \pm 0.51$ \\
\hline $\begin{array}{c}\text { 1-OHP after }(\mu \mathrm{mol} / \mathrm{mol} \\
\text { creatinine) }\end{array}$ & $0.47 \pm 0.22$ & $0.28 \pm 0.20$ & $0.98 \pm 0.76$ & $0.56 \pm 0.53$ \\
\hline FVC before (L) & $5.02 \pm 0.49$ & $5.25 \pm 0.73$ & $5.19 \pm 0.90$ & $5.16 \pm 0.70$ \\
\hline FVC after (L) & $5.06 \pm 0.47$ & $5.28 \pm 0.88$ & $5.17 \pm 1.02$ & $5.18 \pm 0.79$ \\
\hline FEV1 before (L) & $4.09 \pm 0.36$ & $4.05 \pm 0.69$ & $4.12 \pm 0.76$ & $4.08 \pm 0.60$ \\
\hline FEV1 after (L) & $4.02 \pm 0.34$ & $4.04 \pm 0.76$ & $4.03 \pm 0.83$ & $4.03 \pm 0.65$ \\
\hline ICAM-1 before (ng/mL) & $38.1 \pm 5.4$ & $34.9 \pm 5.6$ & $30.0 \pm 6.1$ & $34.4 \pm 6.4$ \\
\hline ICAM-1 after (ng/mL) & $41.7 \pm 9.1$ & $37.9 \pm 7.4$ & $30.7 \pm 9.1$ & $36.8 \pm 9.3$ \\
\hline VCAM-1 before (ng/mL) & $101.4 \pm 11.8$ & $90.5 \pm 25.7$ & $82.2 \pm 16.9$ & $91.3 \pm 20.1$ \\
\hline VCAM-1 after (ng/mL) & $114.5 \pm 20.6$ & $104.3 \pm 36.1$ & $89.9 \pm 24.3$ & $103.0 \pm 28.7$ \\
\hline $\begin{array}{l}\text { DNA strand breaks before } \\
\text { (lesions } / 10^{6} \mathrm{bp} \text { ) }\end{array}$ & $0.13 \pm 0.04$ & $0.14 \pm 0.05$ & $0.09 \pm 0.02$ & $0.12 \pm 0.04$ \\
\hline $\begin{array}{l}\text { DNA strand breaks after } \\
\text { (lesions } / 10^{6} \mathrm{bp} \text { ) }\end{array}$ & $0.14 \pm 0.04$ & $0.12 \pm 0.05$ & $0.13 \pm 0.04$ & $0.13 \pm 0.04$ \\
\hline $\begin{array}{l}\text { Fpg-sensitive sites before } \\
\text { (lesions } / 10^{6} \mathrm{bp} \text { ) }\end{array}$ & $0.47 \pm 0.07$ & $0.44 \pm 0.05$ & $0.49 \pm 0.08$ & $0.47 \pm 0.07$ \\
\hline $\begin{array}{l}\text { Fpg-sensitive sites after } \\
\text { (lesions } / 10^{6} \mathrm{bp} \text { ) }\end{array}$ & $0.40 \pm 0.07$ & $0.43 \pm 0.08$ & $0.41 \pm 0.05$ & $0.41 \pm 0.07$ \\
\hline
\end{tabular}

$\Sigma \mathrm{PAH}$, total polycyclic aromatic hydrocarbons; 1-OHP, 1-hydroxypyrene; ICAM-1, intercellular cell adhesion molecule 1; VCAM-1, vascular cell adhesion molecule 1.

a levels were only measured in 9 firefighters (7 from day 1, 1 from day 2 and 1 from day3) 
Table III - Levels of outcome markers before and after the $24 \mathrm{~h}$ work shift (mean \pm standard deviation) in 22 firefighters, stratified by self-reported information on smoke exposure during the work shift.

\begin{tabular}{|c|c|c|c|}
\hline & Outcome & Before work shift & After work shift \\
\hline \multirow{13}{*}{ 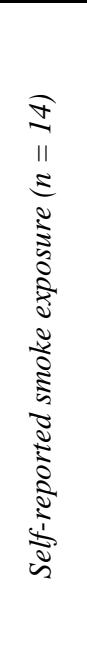 } & $\Sigma \mathrm{PAH}\left(\mu \mathrm{g} / \mathrm{m}^{2}\right)$ & $205.3 \pm 83.9$ & $181.2 \pm 60.4^{\mathrm{a}}$ \\
\hline & 1-OHP ( $\mu \mathrm{mol} / \mathrm{mol}$ creatinine) & $0.66 \pm 0.59$ & $0.67 \pm 0.57$ \\
\hline & FVC (L) & $5.04 \pm 0.62$ & $5.06 \pm 0.71$ \\
\hline & FVC (\%) & $105 \pm 8.0$ & $105 \pm 8.3$ \\
\hline & FEV1 (L) & $4.02 \pm 0.48$ & $3.96 \pm 0.55$ \\
\hline & FEV1 (\%) & $102 \pm 7.5$ & $100 \pm 7.4$ \\
\hline & FEV1/FVC & $80.0 \pm 6.20$ & $78.4 \pm 6.80$ \\
\hline & CRP (mg/ml) & $1.04 \pm 0.68$ & $1.79 \pm 3.50$ \\
\hline & SAA (mg/mL) & $38.4 \pm 33.0$ & $54.4 \pm 91.2$ \\
\hline & ICAM-1 (ng/mL) & $34.0 \pm 7.0$ & $36.8 \pm 9.8$ \\
\hline & VCAM-1 (ng/mL) & $91.3 \pm 18.1$ & $103.3 \pm 22.5$ \\
\hline & $\begin{array}{l}\text { DNA strand breaks } \\
\text { (lesions } / 10^{6} \mathrm{bp} \text { ) }\end{array}$ & $0.11 \pm 0.04$ & $0.14 \pm 0.04$ \\
\hline & $\begin{array}{l}\begin{array}{l}\text { Fpg-sensitive sites } \\
\text { (lesions } / 10^{6} \mathrm{bp} \text { ) }\end{array} \\
\end{array}$ & $0.48 \pm 0.07$ & $0.42 \pm 0.06$ \\
\hline \multirow{11}{*}{ 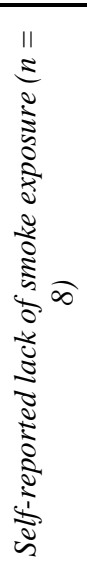 } & $\Sigma \mathrm{PAH}\left(\mu \mathrm{g} / \mathrm{m}^{2}\right)$ & $280.2 \pm 35.4$ & NA \\
\hline & 1-OHP ( $\mu \mathrm{mol} / \mathrm{mol}$ creatinine) & $0.29 \pm 0.18$ & $0.36 \pm 0.42$ \\
\hline & FVC (L) & $5.38 \pm 0.81$ & $5.38 \pm 0.93$ \\
\hline & FEV1 (L) & $4.19 \pm 0.80$ & $4.17 \pm 0.82$ \\
\hline & FEV1/FVC & $77.8 \pm 6.58$ & $77.4 \pm 7.2$ \\
\hline & CRP (mg/mL) & $1.81 \pm 3.29$ & $1.59 \pm 2.41$ \\
\hline & SAA (mg/mL) & $46.6 \pm 59.7$ & $29.3 \pm 31.4$ \\
\hline & ICAM-1 (ng/mL) & $35.1 \pm 5.5$ & $36.9 \pm 9.1$ \\
\hline & VCAM-1 (ng/mL) & $91.23 \pm 24.5$ & $102.4 \pm 39.2$ \\
\hline & $\begin{array}{l}\begin{array}{l}\text { DNA strand breaks } \\
\text { (lesions } / 10^{6} \mathrm{bp} \text { ) }\end{array} \\
\end{array}$ & $0.13 \pm 0.05$ & $0.12 \pm 0.04$ \\
\hline & \begin{tabular}{|l|} 
Fpg-sensitive sites \\
(lesions $/ 10^{6} \mathrm{bp}$ )
\end{tabular} & $0.44 \pm 0.05$ & $0.41 \pm 0.08$ \\
\hline
\end{tabular}

1-OHP, 1-hydroxypyrene; FVC, forced vital capacity; FEV1, forced expiratory volume after 1 second; CRP, C-reactive protein; SAA, serum amyloid protein; ICAM-1, intercellular cell adhesion molecule 1; VCAM-1, vascular cell adhesion molecule 1; NA not analysed.

a levels were only measured in 9 firefighters, all 9 with self-reported exposure to smoke (7 from day 1, 1 from day 2 and 1 from day3) 
Table IV - Percent changes (95\% confidence interval) in outcome levels estimated by mixed effects model using work period or self-reported exposure as predictors

\begin{tabular}{|l|l|l|}
\hline Outcome & Work period & Smoke exposure \\
\hline $1-\mathrm{OHP}$ & $-0.5(-50.0 ; 40.6)$ & $26.5(-31.8 ; 84.8)$ \\
\hline FVC & $0.5(-1.1 ; 2.1)$ & $0.4(-1.7 ; 2.4)$ \\
\hline FVC1 & $-0.7(-2.4 ; 1.0)$ & $-1.6(-3.7 ; 0.4)$ \\
\hline FVC1/FVC & $-1.2(-2.8 ; 0.3)$ & $\mathbf{- 1 . 9}(-3.7 ;-\mathbf{0 . 1})$ \\
\hline CRP & $28.6(-51.4 ; 109)$ & $46.1(-47.6 ; 140)$ \\
\hline SAA & $9.2(-57.9 ; 76.3)$ & $42.3(-41.1 ; 127)$ \\
\hline ICAM-1 & $\mathbf{1 0 . 0}(\mathbf{3 . 7} ; \mathbf{1 6 . 2})$ & $7.4(-0.9 ; 15.8)$ \\
\hline VCAM-1 & $\mathbf{1 5 . 0}(\mathbf{7 . 0} ; \mathbf{2 3 . 0})$ & $\mathbf{1 2 . 1}(\mathbf{1 . 3} ; \mathbf{2 2 . 8 )}$ \\
\hline DNA strand breaks & $4.9(-13.1 ; 22.9)$ & $18.2(-1.4 ; 37.8)$ \\
\hline Fpg-sensitive sites & $\mathbf{- 9 . 1 ( - 1 6 . 9 ; - 1 . 4 )}$ & $\mathbf{- 1 1 . 1 ( - 1 9 . 3 ; - 3 . 0 )}$ \\
\hline
\end{tabular}

1-OHP, 1-hydroxypyrene; FVC, forced vital capacity; FEV1, forced expiratory volume after 1 second; CRP, C-reactive protein; SAA, serum amyloid protein; ICAM-1, intercellular cell adhesion molecule 1; VCAM-1, vascular cell adhesion molecule 1. 